\title{
Hubungan Pemberian Informasi pada Pasien Rawat Inap dengan Kepuasan Mutu Pelayanan Pasien di Unit Admisi RSUP DR. Sardjito Yogyakarta
}

\author{
Maryono', Imram Radne Rimba Putri ${ }^{2}$, Aini Inayati ${ }^{3}$ \\ ${ }^{1}$ Unit Admisi RSUP Dr. Sardjito Yogyakarta, Indonesia \\ ${ }^{2}$ Administrasi Rumah Sakit Universitas Alma Ata, Yogyakarta, Indonesia \\ ${ }^{3}$ Profesi Ners Universitas Alma Ata, Yogyakarta, Indonesia \\ Email: imramradne@almaata.ac.id
}

\begin{abstract}
Abstrak
Proses admisi merupakan pintu utama dalam mendapatkan fasilitas pelayanan kesehatan. Informasi pasien diberikan mulai dari pasien baru reservasi rawat inap hingga pasien pulang. Informasi-informasi mengenai layanan rawat inap sangat dibutuhkan oleh pasien dan keluarga. Informasi tersebut akan meningkatkan pengetahuan pasien dan keluarga dalam tata cara rawat inap. Sikap dan komunikasi yang jelas dari pemberi informasi akan mempengaruhi kualitas pelayanan yang diberikan. Pemantauan terhadap tingkat kepuasan pasien tentunya menjadi target rumah sakit untuk selalu berkembang dan dapat bersaing dengan rumah sakit lainnya. Sehingga diperlukan penilaian kepuasanpasien terhadap pemberian informasi pada pasien rawatinap di Unit Admisi. Penelitian ini bertujuan untuk mengetahui hubungan pemberian informasi pada pasien rawat inap dengan kepuasan mutu pelayanan pasien di Unit Admisi RSUP Dr. Sardjito Yogyakarta. Penelitian ini merupakan penelitian kuantitatif dengan pendekatan cross sectional study. Pengambilan sampel dengan purposive sampling dan melibatkan 96 responden. Pengumpulan data menggunakan checklist kesesuaian pemberian informasi dan kuesioner kepuasan pasien. Data dianalisis menggunakan uji statistik Spearman Rho. Hasil dari uji Spearman Rho didapatkan pemberian informasi awal kepada pasien rawat inap yang sesuai SOP yaitu $60,4 \%$, kurang sesuai SOP $39,6 \%$, kepuasan mutu pelayanan pasien sangat puas $36,5 \%$, puas $47,9 \%$, tidak puas $15,6 \%$ dengan $p$ value $<0,05$, sehingga menunjukkan adanya hubungan yang signifikan pada pemberian informasi pasien rawat inap dengan kepuasan mutu pelayanan pasien di unit admisi, dimana $p$ value $=0,021$. Kesimpulan penelitian ini terdapat hubungan yang signifikan antara pemberian informasi pada pasien rawat inap dengan kepuasan mutu pelayanan pasien di Unit Admisi.
\end{abstract}

Kata Kunci: Pemberian Informasi; Rawat Inap; Admisi; Kepuasan Pasien

\section{Nursing Knowledge About Morse Fall Scale Assessment With Compliance of Re-Assessment of Falling Risk}

\begin{abstract}
Admission become primary gate in accessing health service facility. Information is given to patients when they take inpatient reservation till discharge process. Information about inpatient service were needed by patients and their family. The information will increase patient and family knowledge in getting inpatient procedure. Clear communication and best gesture will influence the service quality. Patient satisfaction level monitoring will be hospital target in developing and competiting with another hospital. Therefore, evaluation of patient satisfaction with the information delivery to the inpatient at admission unit is needed. This research aims to explore the correlation between providing information to the inpatients with the quality satisfaction of patient service at Admission Unit, Dr. Sardjito General Hospital, Yogyakarta. This is a quantitative research with cross sectional study approachment, the participants were selected by using purposive sampling technique, resulting in 96 responden recruited. The research data were collected with standardized providing information checklist and patient satisfaction questionnaires. The collected data were analyzed by using the Spearman Rho. The result of spearman rho there are provided information appropriate with standardized 60,4 \%, not appropriate $39,6 \%$, patient satisfaction very satisfied $36,5 \%$, satisfied $47,9 \%$, not satisfied $15,6 \%$ with $p$ value $<0,05$, with the result that there are a significant
\end{abstract}


correlation between provided information to the inpatients with patient quality satisfaction of patient service at admission unit in which the $p$ value $=0,021$. The conclusion is there are a significant correlation between provided information to the inpatients with the quality satisfaction of patient service.

\section{Keywords: Providing Information; Inpatient; Admission; Patient Satisfaction}

Received: 17/01/2020; Published: 01/05/2020

\section{PENDAHULUAN}

Peningkatan kualitas pelayanan kesehatan sudah menjadi tujuan harian bagi para tenaga kesehatan profesional dan sistem penyedia layanan secara menyeluruh. Kepuasan pasien yang merupakan dimensi penting dari kualitas dan hasil perawatan pasien, menjadi cara ukur kinerja yang bernilai, relatif murah dan konvensional untuk mengkaji konsistensi kualitas perawatan pasien. Kepuasan pasien telah digunakan dalam berbagai situasi untuk menilai keunggulan perawatan, pola perawatan dan sistem layanan kesehatan (1).

Proses admisi sering dianggap sebagai pintu utama pengalaman mendapatkan fasilitas pelayanan kesehatan. Kesan pertama selama interaksi awal antara petugas kesehatan dengan pasien sangat penting untuk menentukan pengalaman yang positif. Proses admisi menjadi salah satu prosedur yang paling berkontribusi secara signifikan terhadap primanya kualitas pelayanan yang diberikan. Rumah sakit perlu memahami kepuasan pasien untuk meningkatkan pelayanan klinis, mengumpulkan informasi tentang performa staf, dan menghasilkan ide untuk pengembangan prosedur administrasi (2).

RSUP Dr. Sardjito merupakan fasilitas kesehatan tersier bertipe A, yang menjadi rumah sakit rujukan pusat nasional dan berkontribusi sebagai instansi pendidikan dalam mendidik calon-calon tenaga kesehatan di masa mendatang. Salah satu misi RSUP Dr. Sardjito adalah pemberian pelayanan kesehatan yang prima, berstandar internasional dan terjangkau oleh semua kalangan masyarakat melalui pembinaan tanggung jawab korporasi dan profesi. Pelayanan prima dan berkualitas dalam memenuhi keinginan pelanggan dapat dinilai dengan beberapa cara, di antaranya melalui system keluhan dan saran, survei kepuasan pasien, serta pengamatan pada kepuasan pasien. Pemantauan terhadap tingkat kepuasan pasien tentunya menjadi target rumah sakit untuk selalu berkembang dan dapat bersaing dengan rumah sakit lainnya. Target sasaran dalam evaluasi kepuasan pasien adalah pelayanan publik, standar pelayanan, dan pemberian informasi dan edukasi (3).

Studi pendahuluan yang dilakukan di RSUP Dr. Sardjito diketahui bahwa data di unit admisi menunjukkan jumlah reservasi di tahun 2019 tercatat di bulan April sebanyak 2.244, bulan Mei sebanyak 2.235, dan bulan Juni sebanyak 2.461. Selama tahun 2018, akumulasi jumlah pasien yang masuk rawat inap sebanyak 42.666, meliputi IRNA I 30.025, IRNA II 5.584, IRNA III 4.237, IRNA IV 306, dan IRNA V 2.514. Menurut hasil survei kepuasan pasien 
RSUP Dr. Sardjito di tahun2018, didapatkan hasil ketidakpuasan pasien yang ditemukan di RSUP Dr. Sardjito sejumlah 16,48 \% terdapat pada bagian pelayanan medis dan keperawatan, pelayanan informasi dan administrasi, pelayanan admisi, pelayanan obat dan resep (kefarmasian), dan beberapa pelayanan lainnya (4). Hal ini juga diperkuat dengan masih adanya keluhan-keluhan dari pasien, baik yang disampaikan secara langsung kepada tenaga kesehatan maupun melalui kotak saran yang disediakan. Target yang hendak dicapai oleh rumah sakit adalah peningkatan BOR sebesar $85 \%$ dan efektivitas program > $90 \%$ melalui survei kepuasan pasien. Dari uraian data di atas, maka penulis tertarik melakukan penelitian untuk mengetahui hubungan pemberian informasi pada pasien rawat inap dengan kepuasan mutu pelayanan pasien di Unit Admisi RSUP Dr. Sardjito Yogyakarta.

\section{BAHAN DAN METODE}

Penelitian ini merupakan penelitian kuantitatif dengan menggunakan pendekatan cross sectional study, dengan variabel independent berupa pemberian informasi pada pasien rawat inap di unit admisi dan variable dependen berupa kepuasan mutu pelayanan pasien yang dinilai serta diamati dalam sekali waktu. (5) Populasi penelitian yaitu pasien yang akan menjalani rawat inap di RSUP Dr. Sardjito melalui unit admisi, dan populasi terjangkaunya adalah pasien yang melakukan reservasi dan langsung mendapatkan kamar untuk rawat inap. Pengambilan sampel menggunakan teknik purposive sampling pada populasi berdasarkan rata-rata jumlah reservasi pasien dalam tiga bulan, dengan perhitungan jumlah sampel menggunakan rumus Slovin dan tingkat kesalahan $10 \%$, didapatkan hasil sejumlah 96 sampel. Penelitian dilakukan di Unit Admisi RSUP Dr. Sardjito pada bulan Januari 2020. Data diambil menggunakan ceklist kesesuai pemberian informasi dengan standar operasional prosedur (SOP) dan kuesioner kepuasan mutu pelayanan pasien. Data yang diperoleh diolah dan dianalisa menggunakan uji spearman rho.

\section{HASIL DAN PEMBAHASAN}

Hasil dan pembahasan penelitian dengan judul Hubungan Pemberian Informasi Pada Pasien Rawat Inap Dengan Kepuasan Mutu Pelayanan Pasien di Unit Admisi RSUP DR. Sardjito Yogyakarta. Memberikan gambaran karakteristik responden (jenis kelamin, Usia, Pendidikan, Pekerjaan, pendapatan) pasien yang akan menjalani Rawat Inap di Unit Admisi RSUP Dr. Sardjito Tahun 2020. Kesesuaian Pemberian Informasi dengan SOP pada Pasien Rawat Inap di Unit Admisi RSUP Dr. Sardjito Tahun 2020. kepuasan mutu pelayanan akan pemberian informasi pasien rawat inap di Unit Admisi RSUP Dr. Sardjito Tahun 2020. Hasil penenilitan ini disajikan dalam bentuk tabel di bawah ini. Karakteristik responden disajikan sesuai dengan tujuan penelitian dan diuraikan sebagai berikut: 
Tabel 1 Karakteristik Responden Pasien yang akan Menjalani Rawat Inap di Unit Admisi RSUP Dr. Sardjito Tahun $2020(n=96)$

\begin{tabular}{|c|c|c|}
\hline Karakteristik & Frekuensi (f) & Persentase (\%) \\
\hline \multicolumn{3}{|l|}{ Jenis Kelamin } \\
\hline Laki-laki & 50 & 52,1 \\
\hline Perempuan & 46 & 47,9 \\
\hline \multicolumn{3}{|l|}{ Usia } \\
\hline $18-30$ tahun & 30 & 31,3 \\
\hline $31-40$ tahun & 27 & 28,1 \\
\hline $41-50$ tahun & 0 & 0 \\
\hline $51-60$ tahun & 13 & 13,5 \\
\hline$\geq 61$ tahun & 2 & 2,1 \\
\hline \multicolumn{3}{|l|}{ Pendidikan } \\
\hline SD & 11 & 11,5 \\
\hline SMP & 15 & 15,6 \\
\hline SMA & 41 & 42,7 \\
\hline Perguruan Tinggi & 29 & 30,2 \\
\hline \multicolumn{3}{|l|}{ Pekerjaan } \\
\hline PNS & 8 & 8,3 \\
\hline Petani & 11 & 11,5 \\
\hline $\begin{array}{l}\text { Pegawai Swasta } \\
\text { Lainnya (Buruh, }\end{array}$ & 31 & 32,3 \\
\hline Pensiunan) & 46 & 47,9 \\
\hline \multicolumn{3}{|l|}{ Pendapatan } \\
\hline$<1 \mathrm{Jt}$ & 30 & 31,3 \\
\hline $1-2 \mathrm{Jt}$ & 29 & 30,2 \\
\hline $2-3 \mathrm{Jt}$ & 20 & 20,8 \\
\hline$>3 \mathrm{Jt}$ & 17 & 17,7 \\
\hline \multicolumn{3}{|c|}{ Lokasi Akses ke Rumah Sakit } \\
\hline Dalam Kota Yogyakarta & 46 & 47,9 \\
\hline Luar Kota Yogyakarta & 50 & 52,1 \\
\hline Total & 96 & 100 \\
\hline
\end{tabular}

Responden pasien laki-laki lebih banyak dibandingkan dengan responden pasien perempuan. Hal yang serupa ditunjukkan pada penelitian di Jinnah Hospital Pakistan, dimana pasien yang melakukan administrasi di admisi lebih banyak berjenis kelamin laki-laki dibandingkan perempuan (6). Usia responden dalam penelitian ini terbanyak pada rentang usai 18 - 30 tahun. Pada usia ini adalah usia yang produktif sehingga untuk mendampingi dan menunggu orang yang sakit diperlukan kondisi yang optimal. Hal ini didukung dengan penelitian terdahulu yang menyatakan rentang usia terbanyak saat menjalani prosedur admisi dan rawat inap berada pada usia $<30$ tahun (7). Data tingkat pendidikan memperlihatkan responden sebagian besar berpendidikan SMA. Hal serupa 
ditemukan pada penelitian terdahulu yang menyatakan sebagian besar pasien yang menjalani rawat inap memiliki pendidikan SMA atau setingkatnya (8).

Jenis pekerjaan responden mayoritas berstatus sebagai buruh dan pensiunan. Hal ini didukung Statistik Ketenagakerjaan Provinsi DIY tahun 2017-2018 yang menunjukkan persentase terbanyak status pekerjaan adalah buruh (44,32 \%), dibandingkan dengan jenis pekerjaan lainnya (9). Pendapatan responden dalam penelitian ini sebagian besar < 1 juta dan 1 - 2 juta. Hal ini didukung dengan mayoritas pekerjan responden adalah sebagai buruh dan pensiunan. Data dari Disnakertrans DIY menunjukkan tren Upah Mininum Kabupaten atau Kota (UMK) tahun 2014-2019 berada pada rentang 1 juta - 2 juta (9). Data karakteristik lokasi akses memperlihatkan bahwa sebagian besar responden yang menjalani proses admisi berasal dari luar kota. Hal ini didasari oleh RSUP Dr. Sardjito sebagai rujukan tertinggi untuk Daerah Istimewa Yogyakarta dan Jawa Tengah bagian Selatan. Rujukan yang diberikan berupa rujukan pelayanan medis, rujukan pengetahuan maupun keterampilan medis dan non medis. Dengan keberadaan tenaga medis yang berkualitas dan peralatan yang canggih, penanganan medis di rumah sakit ini selalu mengikuti perkembangan ilmu pengetahuan dan teknologi kedokteran (10). Keputusan Menteri Kesehatan RI No. HK.02.02/Menkes/390/2014 menetapkan bahwa RSUP Dr. Sardjito menjadi salah satu rumah sakit rujukan nasional, dengan kriteria menjadi rujukan lintas provinsi yang dapat mengampu pasien sekurangnya dari empat provinsi (11).

\section{Pemberian Informasi pada Pasien di Unit Admisi}

Tabel 2 Kesesuaian Pemberian Informasi dengan SOP pada Pasien Rawat Inap di Unit Admisi RSUP Dr. Sardjito Tahun $2020(n=96)$

\begin{tabular}{lll}
\hline Pemberian Informasi & $\mathbf{n}$ & $\%$ \\
\hline Sesuai & 58 & 60,4 \\
Kurang sesuai & 38 & 39,6 \\
\hline Total & 96 & 100
\end{tabular}

Pemberian informasi disini yang dimaksud adalah kesesuaian pemberian informasi dengan SOP penerimaan pasien baru pada pasien rawat inap di unit admisi RSUP Dr. Sardjito Berdasarkan 96 responden. Proses pemberian informasi pasien rawat inap di unit admisi, masih terdapat prosedur yang kurang sesuai dengan SOP. Sebanyak 38 pemberian informasi $(39,6 \%)$ yang dilakukan oleh petugas admisi kurang sesuai dengan SOP dan yang sesuai dengan SOP sejumlah 58 pemberian informasi (60,4\%). Data pemberian informasi pada pasien rawat inap di unit admisi menunjukkan sesuai dengan SOP yaitu 60,4\% akan tetapi ada beberapa informasi yang tidak disampaikan oleh petugas admisi. Hal ini menggambarkan kinerja sebagian petugas admisi tidak patuh terhadap standar prosedur yang ada. Kinerja yang kurang patuh terhadap standard prosedur bisa dipengaruhi oleh beberapa faktor, seperti motivasi, keberadaan supervisi dan penghargaan (12). 
Terdapat beberapa faktor yang dapat mempengaruhi kinerja perawat saat memberikan pelayanan, yakni faktor internal dan eksternal. Faktor internal adalah suatu hal yang berhubungan dengan kecerdasan, keterampilan, kestabilan emosi, emosi serta sifat individu (sikap, kepribadian, fisik, keinginan, motivasi, umur, jenis kelamin, pendidikan, pengalaman kerja, latar belakang dan budaya dan lain sebagainya). Faktor eksternal merupakan faktor yang mempengaruhi kinerja perawat yang berasal dari luar individu tersebut, meliputi peraturan ketenagakerjaan, keinginan pelanggan, pesaing, kondisi ekonomi, kebijakan organisasi, kepemimpinan, tindakan rekan kerja, jenis latihan dan pengawasan, reward, serta lingkungan social (13). Adanya motivasi kerja yang tinggi akan meningkatkan kerja perawat secara langsung. Menurut penelitian terdahulu motivasi juga berkaitan dengan kebutuhan pokok manusia yang terdiri dari existence needs atau kebutuhan akan keberadaan, relatedness needs atau kebutuhan berhubungan dan growth needs atau kebutuhan untuk berkembang. Dalam meningkatkan motivasi kerja seseorang maka ketiga kebutuhan pokok manusia tersebut sedapat mungkin terpenuhi (14).

Supervisi juga memegang peranan penting dalam suatu manajemen keperawatan. Kondisi ini dikarenakan melalui supervisi dapat mengatasi masalah yang ada di dalam organisasi dengan cepat. Supervisor dapat dianggap sebagai figure ayah dimana dapat mengawasi, mengarahkan dan menampung segala keluhan yang berkaitan dengan pekerjaan maupun masalah pribadi yang dapat menghambat kinerja perawat. Sehingga prosedur-prosedur pelayanan keperawatan dapat terlaksana sesuai dengan SOP yang ada, dan meminimalkan resiko komplain dari pasien (15).

Hasil dalam penelitian ini juga didukung oleh penelitain terdahulu bahwa sebagian besar perawat dalam melaksanakan pelayanan keperawatan belum sesuai dengan SOP yang ditetapkan oleh rumah sakit, meskipun setiap SOP sudah disosialisasikan kepada seluruh pihak yang berkompeten untuk melaksanakannya. Sebuah SOP adalah suatu set instruksi yang memiliki suatu prosedur pasti atau terstandarisasi, tanpa kehilangan keefektifannya (16).

\section{Responden berdasar Kepuasan Mutu Pelayanan}

Tabel 3 Kepuasan Mutu Pelayanan akan Pemberian Informasi Pasien Rawat Inap di Unit Admisi RSUP Dr. Sardjito Tahun 2020 ( $n=96)$

\begin{tabular}{lll}
\hline Kepuasan & f & $\%$ \\
\hline Sangat Puas & 35 & 36,5 \\
Puas & 46 & 47,9 \\
Tidak Puas & 15 & 15,6 \\
\hline Total & 96 & 100 \\
\hline at kepuasan & mutu pelayanan & secara keseluruhan berdasarkan
\end{tabular}

respon dari responden. Mayoritas responden menyatakan puas terhadap 
pemberian informasi penerimaan pasien baru pada pasien rawat inap di unit admisi RSUP Dr. Sardjito, yaitu sebanyak 46 responden $(47,9 \%)$. Responden yang menyatakan sangat puas terhadap pemberian informasi di unit admisi sejumlah 35 responden (36,5\%). Tetapi masih ada responden yang menyatakan tidak puas terhadap pemberian informasi di unit admisi, yaitu sejumlah 15 responden (15,6\%), hal ini terjadi karena petugas admisi dalam memberikan informasi mempunyai waktu terbatas, juga disesuaikan dengan informasi yang dibutuhkan pasien. Untuk pasien umum tidak akan dijelaskan mengenai pengurusan BPJS.

Salah satu hal yang mendukung tingkat kepuasan mutu pelayanan adalah pentingnya proses komunikasi. Tim kesehatan khususnya perawat perlu memberikan komunikasi yang baik terkait penyakit, diagnosis, dan perawatan yang diberikan pada pasien. Hal ini dimulai dari awal sebelum pasien menjalani rawat inap hingga pasien pulang. Perlunya kerjasama antar tim kesehatan rumah sakit agar komunikasi berjalan dengan lancar. Tidak hanya perawat bangsal, poliklinik dan unit admisi yang melakukan, namun perawat manager juga melakukan evaluasi terhadap tingkat kepuasan mutu pelayanan dan cara-cara untuk meningkatkan tingkat kepuasan mutu pelayanan. Menurut penelitian terdahulu, terdapat faktor lain yang mempengaruhi kepuasan yaitu terdapat hubungan antara kualitas pelayanan keperawatan dengan kepuasan pasien, penelitian ini pada pasien peserta BPJS diruang ranap kelas III di RSUD Panembahan Senopati Bantul (17).

\section{Analisa Bivariat Hubungan Pemberian Informasi Pasien Rawat Inap dengan Kepuasan Mutu Pelayanan di Unit Admisi.}

Tabel 4 Hasil Tabulasi Silang antara Pemberian Informasi Pasien Rawat Inap dengan

Kepuasan Mutu Pelayanan di Unit Admisi RSUP Dr. Sardjito Tahun 2020 ( $n=96$ )

\begin{tabular}{|c|c|c|c|c|c|c|c|c|c|c|}
\hline \multirow{3}{*}{$\begin{array}{l}\text { Pemberian } \\
\text { Informasi }\end{array}$} & \multicolumn{6}{|c|}{ Tingkat Kepuasan } & \multirow{2}{*}{\multicolumn{2}{|c|}{ Total }} & \multirow[t]{3}{*}{$r$} & \multirow{3}{*}{$\begin{array}{l}\mathrm{p} \\
\text { value }\end{array}$} \\
\hline & \multicolumn{2}{|c|}{ Sangat Puas } & \multicolumn{2}{|c|}{ Puas } & \multicolumn{2}{|c|}{ Tidak Puas } & & & & \\
\hline & $f$ & $\%$ & $f$ & $\%$ & $f$ & $\%$ & $f$ & $\%$ & & \\
\hline Sesuai & 25 & 26 & 27 & 28,1 & 6 & 6,3 & 58 & 60,4 & 0,208 & 0,021 \\
\hline Kurang Sesuai & 35 & 36,5 & 46 & 47,9 & 15 & 15,6 & 96 & 100 & & \\
\hline
\end{tabular}

Berdasarkan hasil uji statistik menggunakan uji spearman rho, didapat nilai $p$ value adalah 0,021 dimana masih kurang dari 0,05 artinya ada hubungan antara pemberian informasi dengan tingkat kepuasan dan dengan koefisien korelasi $(r)=0,208$ mengartikan kekuatan hubungan rendah, lalu $r$ positif berarti arah hubungan positif. Dari hasil uji tersebut menjawab bahwa Hipotesis Ha yang terima, yaitu ada hubungan antara pemberian informasi yang sesuai SOP dengan kepuasan mutu pelayanan. Hal ini menunjukan semakin sesuai pemberian informasi dengan SOP, kepuasan pasien semakin meningkat. Sejalan 
dengan penelitian terdahulu, yaitu terdapat hubungan yang positif antara pelaksanaan discharge planning dengan kepuasan pasien di Ruang Rawat Inap Kelas II dan III RSUD Prof.Dr.W.Z Johannes Kupang. Artinya semakin baik pelaksanaan discharge planning maka semakin tinggi pula tingkat kepuasan pasien (18).

Informasi terkait hak dan kewajiban pasien diberikan mulai dari pasien baru reservasi, rawat inap hingga pasien pulang. Pada saat datang pertama kali, pasien akan bertemu langsung dengan bagian admisi, oleh karena itu unit admisi berkontribusi terhadap pembentukan pola hubungan antara rumah sakit dengan calon pasien dan keluarganya. Bagian admisi mempunyai peranan utama khususnya dalam hal meningkatkan citra rumah sakit. Hal ini dikarenakan pada saat kunjungan pertama dan terakhir kali umumnya akan dilakukan oleh unit ini. Mutu rumah sakit dapat menjadi lebih meningkat dengan peningkatan kualitas pelayanan pemberian informasi di ruang admisi ini. Pasien akan menilai bagaimana derajat kepuasan atau ketidakpuasannya setelah mereka menggunakan dan merasakan sendiri pelayanan keperawatan dan menerima informasi sehingga akan memperbaharui persepsinya mengenai mutu pelayanan yang diterimanya (19).

\section{SIMPULAN DAN SARAN}

Pemberian informasi yang dilakukan pada pasien rawat inap di unit admisi $(60,4 \%)$ sesuai dengan Standar Operasional Prosedur. Tingkat kepuasan mutu pelayanan akan pemberian informasi di unit admisi kategori puas sebesar (47,9\%). Terdapat hubungan yang signifikan antara pemberian informasi pada pasien rawat inap dengan kepuasan mutu pelayanan di Unit Admisi RSUP Dr. Sardjito Yogyakarta, sehingga dapat disimpukan bahwa dalam penelitian ini hipotesis Ha diterima dengan $p$ Value 0,021.

Saran penelitian ini bagi RSUP Dr. Sardjito Yogyakarta diharapkan menjadi pertimbangan pimpinan Unit admisi RSUP Dr. Sardjito untuk memberikan pelatihan secara berkala kepada staf admisi mengenai tatacara pemberian informasikepada pasien rawat inap sesuai dengan SOP yang berlaku dan memberikan pelayanan prima saat melayani proses admisi pasien. Perlu diberikan edukasi kepada tenaga kesehatan untuk selalu patuh terhadap SOP yang ada saat memberikan pelayanan, khususnya pemberian informasi rawat inap. Dengan begitu, kualitas pelayanan yang diberikan tetap sesuai standar, prima, dan bisa lebih berkontribusi menjaga kepuasan serta loyalitas pasien.

\section{DAFTAR PUSTAKA}

1. Legesse M, T S. Adult Patient Satisfaction with In-patient Nursing Care in a Referral and Teaching Hospital in Southern Nations Nationalities and Peoples' Region (SNNPR), Ethiopia. J Nurs Care. 2016;5(334). 
2. Hussain A, Asif $M$, Jameel A, Hwang J. Measuring OPD Patient Satisfaction with Different Service Delivery Aspects at Public Hospitals in Pakistan. Int J Environ Res Public Health. 2019.

3. Handy K, Paynton S. The Admission and Discharge Nurse Role: A Quality Initiative to Optimize Unit Utilization, Patient Satisfaction, And Nurse Perceptions Of Collaboration. Online J Issues Nurs. 2016.

4. Informasi Kepuasan RSUP Sardjito. 2018.

5. Nursalam. Metodologi Penelitian IImu Keperawatan: Pendekatan Praktis. Jakarta: Salemba Medika; 2013.

6. Maroof B, Tasneem SS, Jabeen R, Taskeen R. The Assessment of Patient's Satisfaction and Opinions of their Experience during Admission in the Tertiary Care Hospital. Int J Acad Res Bus Soc Sci. 2019;9(5):555-77.

7. Sreenivas T, Babu NS. A Study on Patient Satisfaction in Hospital (A Study on Three Urban Hospitals in Guntur District, Andhra Pradesh) T. Int J Manag Res Bus Strateg. 2012; Vol.1 No.1:100-18.

8. Akhtari-Zavare M, Yunus Abdullah M, Syed Hassan ST, Binti Said S, Kamali M. Cancer Patients' Satisfaction with Communication and Information Given by Nurses At Teaching Hospitals of Tehran, Iran. Med J Islam Repub Iran. 2011;24(4):212-20.

9. BPS DIY. Statistik Ketenagakerjaan Daerah Istimewa Yogyakarta 20172018. Badan Pus Stat DI Yogyakarta [Internet]. 2018; xii + 50 halaman. Available from: yogyakarta.bps.go.id

10. Profil RSUP Dr. Sardjito [Internet]. Yogyakarta; 2015 [cited 2020 Jan 24]. Available from: https://sardjito.co.id/profil/sejarah/

11. Kementerian Kesehatan RI. Keputusan Menteri Kesehatan RI nomor HK.02.02/Menkes/390/2014 tentang Pedoman Penetapan Rumah Sakit Rujukan Nasional. 2014;1-6।

12. Mandagi FM, Umboh JML, Rattu 3Joy A. M. Analisis Faktor - Faktor yang Berhubungan dengan Kinerja Perawat dalam Menerapkan Asuhan Keperawatan di Rumah Sakit Umum Bethesda GMIM Tomohon. J eBiomedik. 2015;3(3):884-94.

13. Puspitasari NW, Kusumawati FT, Atmanto AP, Zuhri M, Diel MM, Elmonita $Y$, et al. Supervisi Klinik Dalam Pelayanan Keperawatan Sebagai Upaya Peningkatan Kompetensi Perawat Di Rumah Sakit. J perawat Indones. 2018;2(2):51-61.

14. Putri, Imram Radne Rimba, and Elsye Maria Rosa. Analisis Motivasi Kerja Perawat di Ruang Rawat Inap RS PKU Muhammadiyah Yogyakarta Unit II. Jurnal Ners dan Kebidanan Indonesia 3.2 (2015): 82-90.

15. Puspitasari NW, Kusumawati FT, Atmanto AP, Zuhri M, Diel MM, Elmonita $Y$, et al. Supervisi Klinik Dalam Pelayanan Keperawatan Sebagai Upaya Peningkatan Kompetensi Perawat Di Rumah Sakit. J perawat Indones. 2018;2(2):51-61.

16. Natasia N, Loekqijana A, Kurniawati J. Faktor yang Mempengaruhi Kepatuhan Pelaksanaan SOP Asuhan Keperawatan di ICU-ICCU RSUD Gambiran Kota Kediri. J Kedokt Brawijaya. 2014;28(1):21-5.

17. Putri, Imram Radne Rimba. Hubungan Kualitas Pelayanan Keperawatan Dengan Kepuasan Pasien Pengguna BPJS di RSUD Panembahan Senopati Bantul. Indonesian Journal of Hospital Administration 1.2 (2019): 63-69.

18. Stefani M. Hubungan pelaksanaan Discharge Planning dengan kepuasan pasien di ruang rawat inap kelas II dan III RSUD Prof. Dr. W. Z Johannes Kupang. Program Studi Keperawatan Fakultas Keperawatan Universitas Airlangga

19. Waluyo G. Pengaruh Pendidikan Kesehatan Terhadap Kepuasan Pasien Di Ruang Rawat Inap Rsud Kota Madiun. Program Studi Magister Kedokteran keluarga Pascasarjana Universitas Sebelas Maret Surakarta; 2010. 